\title{
Reflections on Cultural Superiority and the Just War: A Neomodern Imperative
}

\author{
By Carlos Escudé \\ Professor of Political Science, Senior Researcher at CONICET \\ and Director of the Centro de Estudios Internacionales \\ y de Educación para la Globalización (CEIEG)
}

\begin{abstract}
If all cultures are morally equivalent, then all individuals are not essentially endowed with the same human rights, because some cultures award some men more rights than are allotted to other men and women. If, on the other hand, all men and women are endowed with the same human rights, then all cultures are not morally equivalent, because cultures that acknowledge that "all men are created equal" are ethically superior to those that do not. These two statements are mutually contradictory and cannot both be true. Moreover, there is a natural conflict between them, leading to inevitable intra and inter-civilizational clashes. Relativism will confront evolutionism and hierarchical theocracy will confront secularized republicanism. This essay takes sides and argues that cultural superiority can be asserted on two different levels: moral and epistemological. A culture that acknowledges a set of universal human rights is superior to one that does not, even if it often deviates from these very norms. A culture capable of delving into nature increasing life expectancy through scientific discovery is superior to one that cannot. Furthermore, waging war to defend a superior culture is a moral imperative.
\end{abstract}

\section{RESUMEN}

Si todas las culturas son moralmente equivalentes, entonces todos los individuos no estamos dotados de los mismos derechos humanos, porque hay culturas que adjudican a algunos hombres más derechos que a otros hombres y mujeres. Si por el contrario todos los individuos poseemos los mismos derechos, entonces todas las culturas no son moralmente equivalentes, porque hay culturas que no reconocen, ni siquiera en principio, la vigencia de esos derechos universales. Las dos afirmaciones son contradictorias y no pueden ser ambas verdaderas. Más aún, existe un conflicto natural entre ellas, conducente a choques entre civilizaciones y al interior de las mismas. El relativismo se enfrentará al evolucionismo y la teocracia jerárquica confrontará con el republicanismo secularizado. Este ensayo toma partido y postula que la superioridad cultural puede afirmarse en dos niveles diferentes: moral y epistemológico. Una cultura que reconoce un conjunto universal de derechos humanos es superior a una que los niega, aunque frecuentemente se desvíe de su cumplimiento. Una cultura capaz de penetrar en la naturaleza elevando la esperanza de vida, es superior a una que no cultiva esa ciencia. Finalmente, librar guerras para defender una cultura superior es un imperativo categórico.

NOTE: The opinions expressed in this paper belong to the author and do not necessarily reflect those of CEMA University. 


\title{
Reflections on Cultural Superiority and the Just War: A Neomodern Imperative*
}

\author{
By Carlos Escudé
}

El sueño de la razón produce monstruos
(Francisco de Goya y Lucientes, Capricho $\mathrm{N}^{\circ} 43$ )

The Neomodern Dilemma

Contemporary humanity faces a major challenge. It must solve a dilemma it does not want to face. If all cultures are morally equivalent, then all human individuals are not essentially endowed with the same human rights, because some cultures award some men more rights than are allotted to other men and women. If, on the other hand, all men and women are endowed with the same human rights, then all cultures are not morally equivalent, because cultures that acknowledge that "all men are created equal" are ethically superior to those that do not. Political correctness counsels the easy way out, asserting both that we all have the same human rights and that all cultures merit the same moral consideration.

Yet the two statements are contradictory. What we can call the liberal-secular Western cultural matrix ${ }^{1}$ (the Matrix) asserts that there is a set of rights and obligations that belongs to humanity qua humanity, irrespectively of positive law and political power. If we make exception to this rule, somewhere, anywhere, then the said rights and obligations are not universal. We can accept the first statement (henceforth Proposition A) or the second (Proposition B). ${ }^{2}$ But we cannot take them both, and one of them must be true. Moreover, this is one conclusion that is beyond relativism and social construction.

\footnotetext{
* I gratefully acknowledge the insightful suggestions of Ira Straus. I am also indebted to Marisa González de Oleaga (UNED, Madrid), Beatriz Gurevich (HBI Scholar-in-Residence, Brandeis) and David Sheinin (Trent University, Ontario) for their comments. Thanks are also due to Trent's History Department and its Otonabee College, which hosted me generously during a sojourn of research, writing and lecturing as the University's Ashley Fellow 2003-2004. This essay is largely the fruit of their hospitality.

${ }^{1}$ The characterization of Western civilization as secularized does not imply that its people are not religious (some are and some are not). It means only that its laws and science are not derived from Scripture.

${ }^{2}$ The other logical alternatives to this pair of statements are totalitarian propositions based on the allegedly essential superiority of one category of human beings over the rest, which I rule out.
} 
With this simple exercise we have shown that such a thing as an objective universal truth exists at both a logical and an ethical level, and that it can be discovered by the human mind. By so doing, we have in very simple terms disproved all postmodern claims to the contrary. And we have also established almost mathematically that a natural conflict rages between both propositions.

This implies inevitable intra and inter-civilizational clashes. Relativism will confront evolutionism and hierarchical theocracy will confront secularized republicanism. If this war escalated to include the totality of the Proposition B's enemies, including both Proposition A relativists and anti-Proposition B religious fundamentalists, it would compromise the entire planet. It would be both a global and a civil war that would follow the historical pattern whereby the anti-relativistic, non-Proposition A opponents of Proposition B tend to become the tactical allies of Proposition B. ${ }^{3}$

\section{The lethal reconstruction of reality}

Proposition B rescues a small nucleus of universal normative truths that are denied not only by some non-Western cultures, but also by certain currents of opinion that are part of the West's core: relativists, multiculturalists, constructivists, postmodernists and subjectivists, all of whom are among this civilization's enemies from within. ${ }^{4}$ These contestatarians are alarmed at what they perceive as the most effective of imperialisms: that of a macro-culture that lends itself to universality by proposing an ethics of tolerance for every cultural trait except intolerance plus a method to delve into external reality and

\footnotetext{
${ }^{3}$ Liberals who opposed the Nüremberg trials on juridical grounds converged with Nazi war criminals put on trial, just as multiculturalists today are the tactical allies of radical Islam.

${ }^{4}$ In moderate versions, cultural relativism can be traced back to Herodotus and the sophists of the $5^{\text {th }}$ Century, and in less remote times to Montaigne and Hume. Its first explicit version is usually attributed to an American political scientist, William Graham Sumner, in 1906. During the first half of the $20^{\text {th }}$ Century, Wittgenstein developed a version linked to linguistics. Simultaneously, Edward Sapir, Benjamin Lee Whorf, and William Van Orman Quine advanced more radicalized versions sometimes referred to as "epistemological relativism" and "cognitive anarchy", which purported the virtual impossibility of intercultural communication and understanding. Although some of the more important conclusions of their linguistics research were later refuted, from then on cultural relativism became the fashionable doctrine and the dominating trend in several fields. In anthropology, Bronislaw Malinowski, Margaret Mead, Ruth Benedict and Mellville Herskovits accompanied the approach. The horrors of the Second World War, the Holocaust and Nazism meant a setback for cultural relativism, but it was shortly lived. Towards the decades of 1970 and 1980, Clifford Geertz and David M. Schneider consolidated the idea that different cultures cannot even be compared. The long list of fashionable European postmodernists who adhere to the doctrine need not be reproduced.
} 
manipulate nature. ${ }^{5}$ Any people can adopt this macro-culture, but inasmuch as its epistemology generates power through the manipulation of nature, it seems to be the only road to knowledge open to humanity and the only culture of universal value. ${ }^{6}$

In their attempt to combat its pseudo-imperialism, relativists and postmodernists fall into a curious solipsism. For a century, indeed since William Graham Sumner and Ludwig Wittgenstein, with ever-growing extremism, they have suggested first and then propounded that all inductive truths from experience are mere social constructions; that the laws of science are hence subjective, or not context-independent. ${ }^{7}$ When confronted with extreme medical examples, the most radical of these prophets will be willing to suggest that cancer can be beautiful if the adequate social construct is at work. ${ }^{8}$ They will seldom come around to saying it, however. Noted American anthropologists have jeered at anti-relativists that condemned headhunters, without ever quite daring to replace "headhunters" with Nazism, and never quite coming round to confessing that their relativism did not extend to the perpetrators of the Holocaust, for if they had, that would have spelled the end of their

\footnotetext{
${ }^{5}$ For a critical analysis of multiculturalism, see Jonathan Rauch, "The Mullahs and the Postmodernists", The Atlantic Monthly, January 2002. See also Aaron Wildavsky, The Rise of Radical Egalitarianism, Lanham, MD: University Press of America, 1991.

${ }^{6}$ Concomitantly with cultural relativism, the opposite tradition, that asserts that cultures are comparable and can be evaluated as superior or inferior, also developed. Unfortunately, the racist opinions of several of the writers and scholars sustaining this idea led to the loss of prestige of the more rational school. Notwithstanding, some of the great liberal minds of the $20^{\text {th }}$ Century were not seduced by the increasing popularity of the relativist approach, which as Karl Popper demonstrated through his theory of knowledge, is scientifically untenable. For the most part, they stuck to some sort of evolutionary scheme, which traces its roots to Darwin and Spencer. Strong anti-relativistic arguments were presented by distinguished scholars like Ralph Linton, Alfred Kroeber, Ernest Gellner, Melford E. Spiro, Dan Sperber, Robert Redfield and George Peter Murdock, but they were not accepted by most mainstream anthropologists.

${ }^{7}$ Although with the advent of postmodernism the universality of scientific knowledge became the target of increasingly radical attacks, this is an issue deeply rooted in the theory of knowledge long before. It takes us back to the problem of induction in Hume and its solution by Popper. Propositional knowledge is accumulated not through the confirmation of "true" hypotheses, but through the elimination of alternative hypotheses that are falsified by empirical data. A Darwinian "natural selection of hypotheses" is at work (see Karl R. Popper, Objective Knowledge: An Evolutionary Approach, Oxford: Clarendon Press, 1972, p. 261). We know more about what is not "true" than about what is. The propositional or conjectural knowledge thus generated is objective, cumulative, and is a dimension of social evolution. Popper's revolutionary paradigm, which was brought into a sharper focus by later contributions such as Hilary Putnam's or Thomas Kuhn's, is challenged by radicals such as Cornel West, who claims that modern forms of rationality, scientificity and objectivity "require the constitution of white supremacy". It would be closer to the truth to say that the Modern Age was made possible (among other things) through the effectiveness of gunpowder and its supremacy, whether used by whites, blacks or yellows.

${ }^{8}$ My thanks to Daniel Pinéu for fruitful exchanges of opinion.
} 
relativism. ${ }^{9}$ As their enlightened French colleague Dan Sperber retorted, such ideas are semi-ideas, such beliefs, semi-beliefs, and such propositions, semi-propositions. ${ }^{10}$

Indeed, relativistic solipsism not only leads to moral neutrality but also to denying there is a terminal reality that is universal to all human beings in the irreparable fact of destroyed human tissue, yet relativists and postmodernists will usually issue their semiideas in such a way as to keep clear from these radical statements. Notwithstanding, when contending with these not-fully-accomplished nihilists it is always useful to bear in mind that the physical reality of death (understood as the final cessation of the vital functions of an animal or plant) is not a social construct even if its "meaning" is interpreted by scores of diverging constructs, and that this self-evident reality is the soundest point of departure for the construction of an objective theory of knowledge.

Analogously, in the realm of civil ethics it is useful to remember that the claim that it is anti-intellectual "to hold some truths to be self-evident," is equivalent to toleration of Adolf Eichmann's genocidal yet lawful deeds. As in the case of Propositions A and B, relativists and postmodernists cannot have it both ways. If moral neutrality is rigorously upheld in consistency with relativism, then their theories are evil and they are, indeed, an enemy within Western Civilization, at a time of war. As Popper could have put it, the open society has enemies, both foreign and domestic. ${ }^{11}$

\footnotetext{
${ }^{9}$ Clifford Geertz, "Distinguished Lecture: Anti Anti-Relativism", American Anthopologist, Vol. 86, № 2 (March 1984), p. 263-273. Geertz's is a brilliant, flippant and dishonest defense of relativism that basically serves to vindicate the better arguments of the anti-relativists.

${ }^{10}$ Dan Sperber, "Apparently Irrational Beliefs", in M. Hollis and S. Lukes (eds.), Rationality and Relativism, Cambridge, MA: MIT Press, 1982, pp. 149-180, cf. C. Geertz, op. cit. p. 274. Sperber's jibe towards relativists in general is justified in writings such as the Geertz article here cited. The latter jeers ever so cleverly while never refuting, as if he felt utter contempt for the logical structure of discourse. He picks on Mary Midgeley, one of the greater anthropologists of the time, for saying in allusion to Nazism that "what we abominate is not optional" (M. Midgeley, Beast and Man: The Roots of Human Nature, Ithaca, NY: Cornell University Press, 1978, p. xiv-xv). But he does not take the final step of declaring his moral neutrality vis-àvis Hitler, or that his personal condemnation of the latter is not objective but context-dependent. Geertz dismisses Popper in less than one sentence, referring ironically to "Popperian 'Great Divide' evolutionism: 'we have science... but they have not"' (op. cit., p. 267). Thus, Geertz and other like-minded doctrinaires fully merit Sperber's sarcasm to the effect that relativism is not even an indefensible position, it doesn't qualify as a position at all. And Geertz's sarcastic quotations of anti-relativists become a boomerang. His citation of Sperber is a good example: "The best evidence against relativists is ... the very activity of anthropologists, while the best evidence for relativists [is] in the writings of anthropologists" (Sperber, op. cit. p. 180, cf. Geertz, op. cit. p. 274).

${ }^{11}$ This language will probably shock pious spirits, but (over and beyond the obvious case of Popper) it has been used by some of the greatest $20^{\text {th }}$ Century thinkers long before the present onslaught of Islamist fundamentalist terrorism and its postmodernist allies. An anthropologist as mainstream as Melford Spiro has pointed out that: "[The] concept of cultural relativism (...) was enlisted (...) against racist notions (...). But
} 
In a way, as A.C. Kors has argued, the relativist, postmodern and constructivist despair vis-à-vis Western Civilization's "colonialism of the mind" is understandable. ${ }^{12}$ Over and beyond all social constructs a ten-year-old corpse is dead. Through this lethal reconstruction of reality we can reaffirm such ancient facts obscured by postmodern sophistry. The world beyond our minds can be explored and discovered, and such discovery has universal value. A fact is a fact. A culture that is capable of enquiry and learning is superior to one that is not. The postmodern denial of this simple reasoning, obvious long before Darwin, is trendy chitchat.

The objective construction of reality begins with a sort of knowledge that belongs to the realm of the natural understanding of the world, in other words, a pre-scientific knowledge presupposed by all scientific articulation. It is one and the same with the realm of "common sense" without which a scientific quest cannot even begin, for it presupposes data processed by our senses that cannot be verified by any instrument. ${ }^{13}$

It suffices with one "bit" of non-socially constructed knowledge to make the point. Reality exists outside our subjectivity, and can be grasped and cast into universally valid assertions. The very progress of both medicine and technologies of mass destruction refutes the purportedly sophisticated rhetoric of postmodern solipsism. The advance of science, both for good and evil purposes, shows that some realities are self-evident, and this is the most important axiom upon which our culture is built. In fact, nothing reaffirms the objectivity of external reality as much as death, which unfortunately lends itself to sophistry much less than life, itself permanently relativized by constructivists. I die hence I

[it] was also used (...) to perpetuate a kind of inverted racism (...), as a powerful tool of cultural criticism, with the consequent derogation of Western culture and of the mentality that it produced." M. Spiro, "Culture and Human Nature", in G. Spindler (ed.), The Making of Psychological Anthropology, Berkeley: University of California Press, 1978, p. 336.

${ }^{12}$ Alan Charles Kors, "The West at the Dawn of the 21st Century: Triumph Without Self-Belief", Newsletter of the Foreign Policy Research Institute's Center for the Study of America and the West, Volume 2, Number 1 , February 2001. It should be noted that some of the pioneers of constructivism are exempted from the charge of "extreme relativism", inasmuch as they do not break away from philosophical realism. Such would be the case of works like Peter L. Berger and Thomas Luckmann's The Social Construction of Reality, New York: Doubleday, 1967. My own work, for that matter, includes constructivist aspects (as in the case of "The Anthropomorphic Fallacy in International Relations Discourse", Working Paper \# 94-6, Center for International Affairs, Harvard University, August 1994, which eventually became the second chapter of my 1997 book, cited further on).

${ }^{13}$ Although knowledge is not limited to what is processed by the senses, it cannot be generated without them. Parmenides was probably the first to reflect, albeit satirically, on the crucial role of our senses: "Most mortals have nothing in their erring intellects unless it got there through their erring senses" (Cf. K. Popper, Conjectures and Refutations, Addendum 8 to the third edition, 1969, p. 408-412). 
exist. I kill hence I exist. I can prevail in the competition for survival; hence my understanding of nature is better than that of the losers. These assertions are contextindependent, valid for all, be they man or woman; black, yellow or white; Moslem, Christian or Jew. To a greater extent than similar propositions concerning positive achievements of science such as life expectancy, which lend themselves more to multiculturalist sophistry, these statements are clearly valid for whoever survives and are clearly irrelevant for whoever did not. While it is outrageous to question the value of life, it is outright impossible to deny the disvalue of death and destruction. They are the missing link; the "bit" of non-socially constructed knowledge needed to refute postmodern fallacy.

Today's liberal-secular West is a culture built on the premises of a knowable external reality that can be made more controllable through human activity, and the transcendent value of the individual. Contrariwise to its historical opponents (including its own religious fundamentalisms of the past and present), this is the culture of all those who have overcome their servitude to the pre-philosophical religious dogmas from which all civilizations have sprung. As such, it is a natural culture with a potential for universalism. Its expansionism is natural (as illustrated by the unconditional embrace of its epistemology by both Russia and Japan ever since Peter the Great and the Meiji era) because it coined "universal categories that transcend its own civilization". ${ }^{14}$ What makes it expansionist, what makes it metaphorically imperialistic, is that it spreads and will continue to do so because it leads to the generation of power through the manipulation of nature. To have come to this is a movement not only of world-time ${ }^{15}$ but also of natural history, ${ }^{16}$ which

\footnotetext{
${ }^{14}$ Alan Charles Kors, op. cit.

${ }^{15}$ I. Wallerstein, The Modern World-System, volumes I to III, New York: Academic Press, 1976, 1980 and 1988. World-time is a useful concept that Immanuel Wallerstein attributes to Wolfram Eberhard (vol. 1, p. 6). It underlines the importance of the global context when an event takes place. For example, it was not the same to industrialize in the 17 th Century (when there were no industrial powers) as in the 20th (when a new industrial state would encounter a competition that Britain did not face during its Industrial Revolution). Straying away from the economic examples Wallerstein would be prone to use, it was not the same for a weak state to violate human rights at the beginning of the 20th Century (when the reach of great powers was much more limited due to a lesser development of technology, and when the United States had not yet developed a thrust to export human rights), as it is at the beginning of the 21 st Century. And total war was far less dangerous before the development of weapons of mass destruction than after their proliferation: a technological world-clock ticks also in this crucial realm. The concept of world-time contributes to the understanding that the "modernization" paradigm of the 1950s and 60s was misguided. It shows that development cannot be understood, as did Walt W. Rostow, in terms of a succession of stages that is similar wherever it takes place (W.W. Rostow, The Stages of Economic Growth: A Non-Communist Manifesto, Cambridge: Cambridge University Press, 1960). It unmasks the fact that countries do not "modernize" politically according to similar patterns, as David Apter understood it, unless they undergo the process in the
} 
recalls Darwin and Spencer. Indeed, despite a clash of civilizations that ultimately stems from ancient conflicts born in the Mediterranean during the early Middle Ages, there is still a lot to be said for Francis Fukuyama's contention that "the end of history" may be near. But such a denouement will not be the product of a triumphant economic system. It can only be the outcome of a superior epistemology in the Popperian sense:

"The growth of our knowledge is the result of a process closely resembling what Darwin called 'natural selection'; that is, the natural selection of hypotheses: our knowledge consists, at every moment, of those hypotheses which have shown their (comparative) fitness by surviving so far in their struggle for existence; a competitive struggle which eliminates those hypotheses which are unfit. (...) The theory of knowledge which I propose is largely Darwinian theory of the growth of knowledge."17

This is why we call it a natural epistemology: it is as natural as life itself, and it generates power because it makes it possible to manipulate nature. The prerequisite for its development was the discovery of nature itself, which was accomplished by the ancient Greeks and their philosophy. The Old Testament does not know "nature", and there is no such term in Biblical Hebrew. The pre-philosophical equivalent of nature is "custom" or

same world circumstances (David E. Apter, The Politics of Modernization, Chicago: University of Chicago Press, 1965). Because world-time conditions processes, neither a country nor a region is a social system in itself. As Wallerstein put it, the only real social system is the world-system. I consider myself a right-wing disciple of Wallerstein, inasmuch as my effort to overcome the economicism of his Marxian approach has led me to conclusions about the ongoing evolution of the world-system that he would never endorse.

${ }^{16}$ Like Wallerstein, I will use the concept of "natural history" to refer to any phenomenon that can be conceptualized in terms of evolutionary "stages". The world-system has a "natural history" if only because human society has undergone a succession of stages in terms of the evolution of technology and the development of its means of production (and destruction).

${ }^{17}$ Emphasis in the original. Popper adds that his assertions are not metaphorical, although they make use of metaphors. Objective Knowledge, p. 261. The logical structure of anthropological approaches that uphold the idea that societies can be evaluated as better or worse is very similar to that of Popper's theory of objective knowledge. Robert D. Edgerton, for example, first sets out to define a "harmful belief or practice" as one that would endanger a person's physical or mental health. He argues that if such practices were present in a family, village or a wider culture, "they would continue to be harmful but another issue would arise: the survivability of the group and its sociocultural system. (...) It requires only little more imagination to think of an entire society whose members are so unhealthy, unproductive and divided among themselves that they inevitably die or are absorbed into another social system". Like a discarded hypothesis that has been falsified, a culture is sometimes discarded in the struggle for survival due to maladaptive traits. "Slavery, infanticide, human sacrifice, witchcraft, torture, female genital mutilation, rape, homicide, feuding and environmental pollution have sometimes been needlessly harmful to some or all members of a society and under some circumstances can threaten social survival" (R.D. Edgerton, The Sick Society, New York: Free Press, 1992, pp. 1 and 16-17). The structure of Edgerton's argument is sound, although it suffers from a little politically- 
"way": quacking is the way of ducks, fighting is the way of soldiers, creating is the way of God. Nature was uncovered when Greek philosophers began the quest for the "beginnings" of all things, and this quest was inconceivable so long as the question was answered according to divine revelation. ${ }^{18}$

Only when this momentous step had been taken could Greek civilization develop its method of disputation, identification of chains of natural causes and effects, and permanent refinement of inductive and deductive thinking. Greece was conquered but its spirit attained hegemony over its Macedonian and Roman successors. The fall of Rome was a tremendous, long-lasting blow, yet Classical culture was transmitted back to barbarian Europe thanks to the Arab scholars whose civilization was then in its zenith.

The Greco-Roman world included most of what is today the Arab world. Yet the rise of Islam alienated Arab culture from its Greco-Roman past. Paradoxically, their learned sages sent back to Western Christendom the cultural matrix that would thrive from the Renaissance onwards, while they created a civilization that also flourished but eventually retreated into a pre-philosophical mindset. Thus, when Christian Europe eventually overcame the tyranny of tradition in issues related to natural knowledge, it had a Greek matrix to fall back to. Its key feature is a philosophical realism that was advocated by Augustine, Thomas Aquinas, Francisco Suárez, Luis de Molina and nearly all major scholastics.

In a way, the primacy of Western epistemology was first established by the selfevident reality of conquest overseas, beginning with the voyages of discovery of the Iberian kingdoms in the $15^{\text {th }}$ Century. The only reason Spaniards and Portuguese were able to sail and conquer, exporting European civilization on a global basis for the first time yet lastingly, is that they understood that a fact is a fact. Prince Henry the Navigator's epistemology descended directly from Aristotle's. Montezuma might have interpreted the coming of the Conquistadors in terms of his culture's social construct, but soon he was no longer there to tell about it, while Hernán Cortés' men remained there and today the descendants of the Aztecs speak Spanish.

correct naiveté: in the $16^{\text {th }}$ Century an empire could not have survived, as such, without slavery, which in that moment of world-time was not a maladaptive but an adaptive trait.

${ }^{18}$ Leo Strauss, Natural Right and History, Chicago and London: The University of Chicago Press, 1950, p. 81-83. 
Cortés conquered an empire with just a few hundred men because the Aztecs did not have a methodology for coping with utterly unexpected events, such as the arrival of the Spaniards. When this happened, Montezuma appealed to his gods to tell him what to do, but they failed him. Contrariwise, Cortés unfolded a rational, secular strategy to set one Mesoamerican tribe against the other, Totonacs against Aztecs, Aztecs against Totonacs, deviously playing friends to both, and landed on top. He could only do this because he had overcome the shackles of his own religion, developing a methodology based on a secular epistemology. As David Gress argued, Spanish atrocities in Mexico were atheistic murders, unlike the Aztec's human sacrifices, which were the dictates of the gods. The former were the acts of modern men who, far from their home, advanced to a sort of "covert secularism" and realized every course of action was open to them. ${ }^{19}$

Similarly, when the unpaid army of Charles V sacked and looted Rome in 1527, the still uncrowned but elected Holy Roman Emperor engaged in covert secularism, teaching the reluctant Papacy who was the puppet and who was the master. His grandfather Ferdinand II of Aragón had acted analogously vis-à-vis his vassal Pope Alexander VI (the Valentian Rodrigo de Borja), and was praised for that and other reasons by Niccolò Machiavelli as the ideal Renaissance prince. At the height of their power, Spanish kings did not need to break with Rome as did England's Henry VIII, because they could manipulate the Vatican as a satellite. Henry, Ferdinand, Charles and Cortés were all covert seculars unrestrained by religion and capable of the most outrageous rational deeds in order to attain their objectives. ${ }^{20}$

Indeed, the source of Western power is and has always been an increasing understanding of the means to control nature, coupled with the parallel understanding that humanity is sovereign and no allegedly divine law can place a limit to a state's actions. Machiavelli's quest for lessons for statesmen, in history and political action, rather than in religion and moral philosophy, is the epitome of this secular and instrumental quality of the Renaissance without which the West and its success cannot be understood. Half a millennium later, the global stability achieved by the nuclear blasts at Hiroshima and

\footnotetext{
${ }^{19}$ David Gress, From Plato to NATO, New York: Free Press, 1998, pages 249-258.

${ }^{20}$ They would all have secretly approved of Nietzsche in Beyond Good and Evil, when he chides Christianity as the personification of a "slave morality" equating goodness with stupidity. Not in public, however: as covert seculars, these Renaissance men were also predecessors of Charles Maurras.
} 
Nagasaki, which lasted half a century, was the crowning achievement of secular humanity's ethical sovereignty.

\section{Power as the natural product of objective knowledge}

Ever since the Iberian voyages of discovery the globe has been one. It has been increasingly interconnected and the West (as a historical identity) has been the rule-maker. When opposing epistemologies are at odds, conquest is a possible test of epistemology, for what is conquest but the triumph of one matrix of cognitive capabilities over another? And what is a war-casualty if not the obliteration of one set of cognitive capabilities by those of its foe? ${ }^{21}$

Indeed, as Gress shows in From Plato to Nato, the Anglo-American "Grand Narrative" that was taught in a myriad courses on Western Civilization before the onslaught of postmodernism, founded on mythical "magic moments" and "original sins", is a caricature of history to no less an extent than the postmodern version itself. The same should be said of Samuel P. Huntington's 2004 book, Who Are We ${ }^{22}$ They echo legends that would make us believe that the development of a free society was the product of an ahistorical succession of lucky breaks. But it was not. "Liberty grew because it served the interests of power". The quest for power is an independent variable. Liberties and the liberal creed are not, no matter how important they may be in the configuration of present day Western identities.

More specifically, and however much it may be denied, in the United States itself liberty also grew only inasmuch as it was functional to the interests of power. Huntington, for one, reminds us of President Andrew Jackson' ethnic cleansing of Indians in the 1830's,

\footnotetext{
${ }^{21}$ A fine illustration of the opposite point of view, which I call "extreme relativism", is represented by Marisa González de Oleaga, who denies outright an evolutionary continuum leading to the increase of cognitive capabilities: "La propuesta de capacidades cognitivas y conceptuales comunes a la especie no establece ninguna jerarquía cultural y no responde a ningún esquema evolutivo" (In "Memoria para el concurso de oposición para la titularidad de la asignatura Teoría e Historia de los Sistemas Sociales", UNED, Madrid 2002, ms. p. 49). She is no less mistaken than is Wallerstein when he claims that "there is no inevitable secular line of human history" ("North-Atlantism in decline", Geopolitics and Geoculture: Essays on the changing world-system, Cambridge UK: Cambridge University Press, 1991, p. 106., p. 106). Sadly, the ability to kill is an objective measure of cognitive and cultural evolution, maybe the only one. Its mere postulation opens the way for an evolutionary theory based on the survival of the fittest. It is in reaction to errors of this kind that I set forth to write this essay.

${ }^{22}$ Samuel P. Huntington, Who Are We? The Challenges to America's National Identity, New York: Simon \& Schuster, 2004.
} 
legally implemented through the Indian Removal Act. The principal tribes in six Southern states were forcibly moved west of the Mississippi ${ }^{23}$. Never mind black slaves.

Notwithstanding, retreating into mythical Grand Narrative, Huntington claims "The principles of the (American) Creed have (...) remained remarkably stable over time."24

Seymour Martin Lipset, as quoted by Huntington, concurs in the Grand Narrative claim that there has been "more continuity than change with respect to the main elements of the national value system". ${ }^{25}$ But of course, in order to draw this conclusion in the light of the ethnic cleansing of Indians and the enslavement of blacks, one must manipulate logic, arguing that what has not had continuity is the cultural contents of the concept "the human individual" (purportedly endowed with an essential dignity, equality, and rights to freedom, justice and a fair opportunity), so that it once did not include Indians and blacks. Only thus can one argue that the Creed has remained "remarkably stable": the structure that holds its elements together is said to have remained the same, while the cultural contents of its most relevant element is acknowledged to have changed!

This, of course, is pure fallacy. There really was no stability of the sort claimed by Huntington, Lipset and many others. Theirs is part of the mythical Grand Narrative. In reality there was a formidable evolution in the Creed, and this evolution is part of the natural history of human rights. There was growing freedom, extending to ever-growing categories of human beings. And this growth was a consequence of the evolution of the interests of power in an ever more developed industrial society.

Abolition, for example, became a mainstream aspiration only among those for whom slavery was no longer a vital economic institution. What made the South different from the North during the American Civil War, first and foremost, was the need for slaves:

\footnotetext{
${ }^{23}$ Ibid, p. 54. This of course led to the Second Seminole War of 1835-1843, very seldom remembered by anyone outside the United States. On the other hand, it was this sort of policy of ethnic cleansing that encouraged the USA to sponsor the creation of Liberia in 1821. Some 11 to 15 thousand free American blacks emigrated to the new state. Huntington himself acknowledges that the extent to which they did so voluntarily "seems to be in doubt". And he reminds his readers that in 1862, President Lincoln told the first group of blacks ever to visit the White House that they should migrate to Africa. Ibid, p. 55. Yet he claims the American Creed has remained stable.

${ }^{24}$ Ibid, p. 67. He quotes several convergent definitions coined by diverse scholars, describing this so-called American Creed. One of the better ones is Lipset's, who finds five key principles at core: "liberty, egalitarianism (of opportunity and respect, not result or condition), individualism, populism, and laissezfaire." See Seymour Martin Lipset, American Exceptionalism: A Double-Edged Sword, New York: Norton, 1996, pp. 63-64.
} 
the difference in creeds was derivative. Analogously, what made Argentina (a country which by 1813 had enacted the freedom of the newly-born offspring of slaves) different from both Brazil and the United States was that it had no significant plantation economies. Of course this led to an abolitionist Argentine creed, but is this even worthy of notice? ${ }^{26}$ Indeed, even such creeds are relevant only when they are useful to the interests of power in powerful states. ${ }^{27}$ Yet notwithstanding the global mythology enveloping the American

Creed, the fact remains that freedom was extended to the offspring of Buenos Aires slaves long before it was conceded to that of Washingtonian ones, simply because slavery was economically relevant for a longer time in southern United States than in Argentina. From the viewpoint of the forces that forge historical process, this, and not the American or Argentine creeds, is the key independent variable.

So we must concur with Gress that liberty grew when and because it served the interests of power. And power is something that grew inevitably out of a natural epistemology, which is really the defining trait of Western Civilization. Indeed, the West is and was about power long before it was about freedom, and rightfully so, for its epistemology is natural and this placed it in a higher phase of the evolutionary continuum. ${ }^{28}$

\section{The West's historical enemy}

Not only this: the West has had a historical enemy which is hardly ever mentioned by mainstream Grand Narrative, ${ }^{29}$ perhaps because it is more difficult to discern as such from the perspective of the powers that became the core of the West only after this foe was

\footnotetext{
${ }^{25}$ Seymour Martin Lipset, The First New Nation: The United States in Historical and Comparative Perspective, New York: Norton, 1973, p. 103.

${ }^{26}$ As in the writings of Juan Bautista Alberdi, whose Bases (1852) inspired the Argentine Constitution, and whose El Crimen de la Guerra (1870), were it American, would contribute to the myth of U.S. exceptionalism, but being peripheral is understandably forgotten.

${ }^{27}$ The same holds true for iniquity. The fact that the American ethnic cleansing of Indians and its obnoxious legal foundations are seldom remembered in conventional lore, while the Spanish expulsion of Jews and Moors in the $15^{\text {th }}$ and $16^{\text {th }}$ Centuries are constantly pointed to, is also a product of the dynamics of power. ${ }^{28}$ This is one of the several reasons why in the future the United States will probably evolve towards a less democratic type of polity. Robert D. Kaplan is one of several authors in vogue who is not afraid to acknowledge this: "The short, limited wars and rescue operations with which we shall be engaged will go unsanctioned by Congress and the citizenry; so too, will pre-emptive strikes against the computer networks of our adversaries and other defense-related measures that in many instances will be kept secret. (...) Going to war will be less and less a democratic decision. (...) War is subject to democratic control only when it is a condition distinctly different from peace”. Robert D. Kaplan, Warrior Politics, New York: Random House, 2002, p. 117 and 121.
} 
(temporarily) defeated. ${ }^{30}$ It was an enemy comparable in power to the Christian West until the Age of Discovery. Known indistinctively as Moors, Saracens, Infidels, Arabs, Moslems or Ottomans, they were on the verge of conquering Christian Europe on more than one occasion. After defeating Spanish Visigoth King Roderick in the 711 battle of Guadalete and invading the entire Iberian Peninsula, they were stopped on the other side of the Pyrenees by Charles Martel in the 732 Battle of Poitiers ${ }^{31}$. Although the Reconquest of the Peninsula proper started early on, with the 722 battle of Covadonga in which the fugitive Don Pelayo defeated the Arabs in Asturias, it was not fully accomplished until 1492, when Ferdinand and Isabella captured Granada. This event was much more talked about in late $15^{\text {th }}$ Century Europe than the discoveries of Columbus.

By then, however, the Ottoman Turks, Islamic heirs to Arab expansionism, had taken Constantinople and become a threat to Western Christendom in the other extreme of Europe. The Ottomans continued their onslaught, conquering the Balkans, much of Hungary, and threatening Vienna on more than one occasion. It was up to Spain, once more, to check the Moslems' expansion, with the power vested on her by the conquest of vast silver-rich overseas territories, and the dynastic inheritance of an empire in continental Europe that included Portugal, the Spanish Netherlands, Milan, Naples, Sicily, Sardinia and a part of Burgundy. The Christian fleet led by an illegitimate half-brother to Philip II, which in addition to the Spanish vessels included allied Vatican, Venetian and Genoese galleys, dealt the Ottomans their first major defeat at sea in the 1571 Battle of Lepanto, off the coast of Greece.

In those days, that is, long before the landmark 1648 Treaty of Westphalia (usually heralded by German-centric international relations theoreticians as the birth date of the modern interstate system), Spain, France and England were full-fledged sovereign,

\footnotetext{
${ }^{29}$ They occupied the place of "the other" that Huntington gives to the American Indians in the forging of the United States.

${ }^{30}$ It may be for this reason that Robert Kagan does not recognize the true magnitude of the threat posed by this present yet ancient enemy. He minimizes the confrontation between the West and radicalized Islam, to the point that he claims that Francis Fukuyama was right about the oncoming of the end of history, as a consequence of the hegemony of liberal-democratic capitalism after the collapse of communism. See R. Kagan, Of Paradise and Power, New York: Knopf, 2003, pp. 80-81. Notwithstanding, one cannot discard the possibility that Kaplan's book is contaminated by diplomatic calculations.

${ }^{31}$ The Catholic Encyclopedia, a less mainstream vehicle of the Grand Narrative, tells us that the Battle of Poitiers "must ever remain one of the great events in the history of the world, as upon its issue depended whether Christian Civilization should continue or Islam prevail throughout Europe".
} 
territorial states. Indeed, if the Grand Narrative is told from the perspective of statebuilding and the concentration of power (without which the West would never have become what it is today), it looks very different from what it seems when told from the vantage point of a mythical pursuit of freedom.

\section{The clear and present danger}

As stated, Western global predominance, an imposing, compelling fact since the Renaissance, is the product of a natural epistemology pioneered by the Greeks, lost to Europe with the Germanic invasions of the Roman Empire, and slowly recovered in the ensuing millennium. The Discoveries of the late $15^{\text {th }}$ Century can safely be considered symbols of the full recovery of the cultural matrix lost with the fall of Rome. Wars between peoples who share this epistemology (including the Cold War between the Soviet Union and the United States) are to some extent intra-Western wars, regardless of the differences in ideology or other spheres. ${ }^{32}$

When we add a liberal civil ethics to our physical epistemology we have what we called the liberal-secular West, which grew out of the Enlightenment and spread gradually through the larger Western historical community and beyond. But this is only a segment of the West, not only inasmuch as not all the societies of the epistemological community can be identified with it, but also because even in its core, some segments of population and interest sectors are not liberal. ${ }^{33}$

The very societies where the Enlightenment was born have always had segments that were anti-modern: the enemy within. Joseph de Maistre and the likes of him contradicted the French Enlightenment; Edmund Burke and his followers placed limits to the English Enlightenment; anti-modern fellow Jews excommunicated Benedict Spinoza from his religious community. Integral Catholicism today opposes the liberalizing trends of

\footnotetext{
${ }^{32}$ Although he later contradicted himself, Huntington asserted that the two world wars and the Cold War were "Western civil wars". He attributes the expression to William Lind. See Samuel P. Huntington, "Clash of Civilizations?", Foreign Affairs, Summer 1993, Vol. 73 (3), p. 23.

${ }^{33}$ Notwithstanding, barring rare exceptions, they are secular in the sense that their law and science does not derive from revealed truths.
} 
a part of the contemporary Church. Postmodernism is even more extreme an enemy inasmuch as some of its expressions tend to justify many deeds of radical Islam. ${ }^{34}$

What we face is a global conflict between modernity and its foes. This is the challenge neomodernism sets out to clarify, in the mist of postmodernist confusion.

Because of its use of suicidal murder as a method that renders it immune to deterrence, and due to the likelihood of its eventual access to weapons of mass destruction, pan-Islamic extremism congregates the most dangerous concentration of these enemies, but is not alone. Our societies are far from monolithic. And the conflict is asymmetric, for although the West is devastatingly more powerful than its enemy, it finds it difficult to wage material war against its law-abiding domestic enemies without betraying its principles, while the anti-modern forces of pan-Islamic extremism can pride themselves of not tolerating significant dissent in their heartland: such intolerance is for them a principle.

Yet we retain the conviction that because the Western cultural Matrix is a natural one, all those who do not share it are fated to subordination and domination, and precisely because this Matrix is natural, it is bound to prevail and be shared eventually by all of humanity, despite its mainly foreign terrorist foes, and regardless of the likes of Jean Baudrillard and Stanley Fish, who for the sake of fame and fun attempt to erode it from within. To attain this victory, however, the Creed must be temporarily subordinated to the functional requisites of war, as has always been the case when the West has fought for survival and supremacy.

\section{$\underline{\text { Natural Law by Default }}$}

In order to build our case for enforcing this "state of exception" that must temporarily suspend some rights and guarantees that are essential to the Matrix, let us now

\footnotetext{
${ }^{34}$ In "The Mullahs and the Postmodernists", Rauch (op. cit.) endorses Aaron Wildavsky's conceptualization, which differentiates between three kinds of cultures: individualistic, hierarchic and egalitarian. The American mainstream is predominantly individualistic. Postmodern leftists are radical-egalitarian. But with Marxism in ruins, "they can offer no viable social system that will reliably produce equal outcomes". Thus they turn toward nihilism - "toward ideology and action that always protest but never propose". On the other hand, Islamic fundamentalism is hierarchism incarnate and could hardly be more different from the postmodernists: "the world will be a just place when Islamic law is the only law, with Muslims ruling infidels, men ruling women, and God ruling man". But "they are less opposites than counterparts in opposition to the dominance of individualism". The postmodernists and the mullahs "are natural enemies, as Stalin and Hitler were (...), but their convergence is as revelatory in today's context as the Hitler-Stalin pact was in 1939, and for much the same reason: it brings two usually opposing pole stars into temporary conjunction, and reminds the rest of us where we stand."
} 
return to the beginning. If, as asserted, Western civilization is based upon the assumptions that there is a natural world outside our cognition patterns, and that the human cognitive process allows for its comprehension and for the accurate communication of such knowledge in an actionable manner, it can be contended that this "natural" realm includes a minimum set of normative elements. Following Hobbes, these norms emerge from the assumption that the organization of human life in polities with domestic power differentials is justified in terms of the interests of the human individual, who is endowed with a transcendent value yet requires a Leviathan (or state) in order to survive. The state is justified only by the individual's need for a social compact that protects his/her inalienable rights.

The centrality of the individual in the Matrix makes it useful to recur once again to the American Declaration of Independence, where it says: "We hold these truths to be selfevident: that all men are created equal...". The clause "self-evident" in this brilliant contention is crucial. It is self-evident because the opposite assertion, that men are created unequal, or that men are superior to women and entitled to rule over them, is self-evidently false. By the same token that we have discovered a natural epistemology that allows an increasing control over nature, liberal-secular humanity has discovered a natural normative epistemology that leads to a small set of normative propositions that we call natural law.

Ours is a "natural" law in the sense that it emerges from an understanding of nature. Just as in the realm of physical knowledge a ten-year-old corpse is self-evidently dead, the law that upholds that the life of the species must be preserved is self-evidently true. Both bits of knowledge belong to the aforementioned realm of the natural understanding of the world, or "common sense". There is no reason why we should give our senses more credit in physical than in normative matters. The metaphysical jump is no greater than in the enunciation of causality vis-à-vis Hume's problem of induction.

Natural law establishes a bridge between the realm of the Is and the realm of the Ought. What is true according to natural law belongs to both realms at once. Human life is a fact and a value at the same time, inasmuch as death is a self-evident physical reality, and the paramount value of life is a self-evident normative truth. Upholding a natural law implies blurring the distinction between facts and values, so dear to Max Weber and many others among the foremost social scientists of the $20^{\text {th }}$ Century. 
On the other hand, the fact that through the course of history as well as in the landscape of human cultures we find a great diversity of opposing ethical conceptions does not prove that natural law as such does not exist. Natural law must be discovered, like nature itself. Just as in the realm of the Is classical philosophy was the quest for the "first things" (for example, the Big Bang or the atom), in the realm of the Ought classical philosophy was the quest for the "right way". To be able to seek the "right way" implies being able to depart from the dictates of traditional authority and accept the dictates of human reason.

It took ages for a segment of humankind to find its way to this sort of knowledge. As Leo Strauss pointed out:

"Some of the greatest natural right teachers have argued that, precisely if natural right is rational, its discovery presupposes the cultivation of reason, and therefore natural right will not be known universally: one ought not even to expect any real knowledge of natural right among savages". 35

There could be no knowledge of natural right in the Old Testament, for the discovery of nature precedes that of natural right. Exactly as in the case of the physical realm, "custom" or "way" is the pre-philosophical equivalent of natural law. If we encounter more than one way for humankind, pre-philosophical humanity's authoritative opinion is that "our" way, as sanctioned by the ancestral custom of one's own ethnic community, is the right way. Until the discovery of nature, ancestral authority answers all questions concerning the right way.

In his Republic, Plato overcame this dictate of authority. Discussion of natural rights began when Cephalus, the aged father, left to take care of his duties with the gods, and it was his absence that made the discussion necessary. ${ }^{36}$ While there was a contact with the gods through the presence of the head of the household, the discussion was unnecessary. Thus the Greeks learnt to shake off the servitude to tradition and make reason paramount.

\footnotetext{
${ }^{35}$ Consider Plato, Republic, 456b12-e2, 452a7-8 and e6-d1; Laches 184d1-185a3; Hobbes, De cive, II, 1; Locke, Two Treatises of Civil Government, Book II, sec. 12, in conjunction with An Essay on Human Understanding, Book I, chap. iii. From Leo Strauss, op. cit., p. 9.

${ }^{36}$ A similar metaphorical rendition is found in his Laws, where the disputants' discussion of natural rights subtly replaces a journey to the cave of Zeus, their original destination to which the reader knows not if they arrive. Strauss's reasoning, is followed closely in these paragraphs.
} 
This did not mean a rejection of the divine, but the recognition that knowledge is possible only through the use of our mind and senses.

Only if authority is doubted can the "first things" and the "right way" become the object of a quest. This in itself implies a quantum jump in terms of the recognition of the rights of man. Acknowledging that humankind has the right to depart from the dictates of ancestral authority through the discovery of a natural law was perhaps the greatest libertarian accomplishment of all times.

In the intellectual history of the West this achievement was eventually blurred when the fathers of the Catholic Church combined natural law with theology. For Thomas Aquinas, natural law continued to mean a law knowable to the human mind unassisted by divine revelation. But he went on to claim that natural reason discovers that the natural law is insufficient and points beyond itself. Natural reason thus "discovers" the divine law, which perfects natural law. Natural law hence becomes inseparable from natural theology and the latter becomes inseparable from revealed theology, cleverly rendering us back to square one. Theology thus absorbed natural law until the Enlightenment, when under the aegis of Thomas Hobbes, John Locke and Benedict Spinoza, the modern natural law conception recovered the liberal quality of the Greek concept.

The Universal Rights of Man, which link the American and French revolutions with the United Nations, could never have been drafted without this libertarian Matrix. It was discovered, it was lost time and again, it was recovered as many times as lost, and it remains in the back of all human minds to be rediscovered by whatever society or culture has not yet done so. But there is only one natural law. Our Propositions A and B are not two opposing conceptions of natural law. ${ }^{37}$ Proposition $\mathrm{A}$ is not natural law at all, but a claim anchored in an extreme and capricious relativism that awards rights not to the human individual but to established cultures, and which is thus the ally of both totalitarianisms and pre-philosophic interpretations of divine law, scripture or its equivalent, themselves enemies of Proposition B. This is a case in which natural law is in a state of ideological war against a set of foreign and domestic conceptions that deny the universal rights of the

\footnotetext{
${ }^{37}$ As I have misleadingly written elsewhere, for the sake of simplicity (C. Escudé, "Natural Law at War", Times Literary Supplement, \# 5174, May 31, 2002). If we accept that there can be such a thing as opposing conceptions of natural law, then it was criminal to execute law-abiding Nazi officials who dutifully obeyed orders.
} 
human individual. This natural war has all of the makings of total war because the foes hold irreconcilable positions about the most relevant of all human affairs. Whether it remains potential or is unleashed into holocaustic belligerence depends on circumstances and opportunity, but it is bound to escalate sooner or later, with full use of weapons of mass destruction, unless their proliferation is effectively and swiftly contained.

Indeed, the stoning of women accused of adultery and the amputation of the limbs of petty criminals are crimes against natural law, yet these atrocities are fully legitimized as acts of justice in certain (though not most) Islamic cultures and legal frameworks, to no less extent than Nazi positive law made it mandatory for Eichmann to obey his orders. Even though both have been interpreted as mandates of natural law, in truth they are manifestations of a dire ignorance of natural law; of a pre-scientific ignorance of human nature. To claims that the Nazi or extremist Islamic legal codes are just another interpretation of natural law we can only respond yet again that there can only be one natural law. Cases such as Eichmann's (who was a law-abiding citizen of his country and a dutiful official of a legal regime) cannot be condemned unless we reject cultural relativism as did, among others, Alain Finkielkraut in La Défaite de la Pensée (1987), Hannah Arendt in The Origins of Totalitarianism (1951) and Julien Benda long before in his classic La Trahison des Clercs (1926). ${ }^{38}$ That extreme cultural relativists do not consider stoning to death and amputations crimes in themselves, because they think such deeds must be evaluated according to the cultural values of the civilization from which they emerge, is the defeat not only of la pensée but of ethics itself. It leads non-stop to nihilism, and it is one reason why a natural-law solution must be adopted despite the logical tensions it poses.

The cliché goes that this implies tolerance to everything except intolerance. But what this actually means is that we must condemn positive laws that violate the natural law, irrespective of the cultural context in which they were enacted. Were it not to selfrighteously ascertain this, the West would lose its hallowed right to revolt against extreme forms of injustice within its own societies. The right to revolt, which is parallel to the obligation to disobey even positively lawful orders that violate the natural law (such as

\footnotetext{
${ }^{38}$ Alain Finkielkraut, La Défaite de la Pensée, Paris: Gallimard, 1987, Hannah Arendt, The Origins of Totalitarianism, New York: Harcourt Brace Jovanovich, 1979, and Julien Benda, La Trahison des Clercs, Paris: J.-J. Pauvert, 1965.
} 
Hitler's), would be lost if it were not contended that there is one and only one natural law. ${ }^{39}$ This may be the reason why, although the West teems with cultural relativists, few if any of the intellectuals who had to flee the Nazis or were in close contact with the Holocaust have been relativists. The paradigmatic case was Einstein, father of the theory of relativity, who openly admitted he was not a cultural relativist.

No positive law can ever enshrine Locke's right to revolt (upheld long before him by Aquinas, Suárez and all the foremost scholastics), because no polity will ever enact laws that establish that it is lawful to rebel against it. The right to revolt is a natural right or is not a right at all. If we forsake it, we succumb to tyranny.

\section{In praise of double standards}

We must therefore accept that there is one and only one natural law, by default. If we do not, we are accepting tyranny be default (because we would be forfeiting our own natural right to revolt against unjust positive laws). But because, as will be argued below, there is a natural history of human rights (i.e., a necessary succession of technologically conditioned stages in the historical implementation of these rights), a hegemonic state should be free to deviate from the norm when an imperative need arises. For example, it should be free not to comply with the natural law that would oblige it to legitimately intervene in the domestic affairs of Saudi Arabia in order to prevent human rights violations, if such intervention would generate losses that would be detrimental to its power (which makes the global defense of human rights possible, even if only selectively). Likewise, if in the case of Al Qaeda prisoners from the Afghan war, it is deemed likely that the propaganda effects of the public trials prescribed by the Third Geneva Convention would engender thousands of new terrorists, the United States must feel free to violate the covenant.

Indeed, historically there is a lot to be said in favor of double-standards in the application of human rights natural law. It is through a double-standard mechanism that humanity has taken enormous strides in the sphere of civil ethics. This is, properly

\footnotetext{
${ }^{39}$ On the subject see, for example, Herbert C. Kelman and V. Lee Lawrence, Crimes of Obedience: Toward a Social Psychology of Authority and Responsibility, New Haven: Yale University Press, 1989.
} 
speaking, the most sophisticated technology for moral advancement ever developed, and as such a triumph of natural epistemology. ${ }^{40}$

For example, the champion of abolitionism was $19^{\text {th }}$ Century Britain, which previously had been one of the most enthusiastic slave-trafficking empires. When thanks to the Industrial Revolution it found itself fifty years ahead of its closest competitors, its Establishment came to the conclusion that slavery was no longer functional to its capitalism, and that it made no sense to let its competitors reap benefits from an immoral system that the British Empire had overcome economically. Although there had always been abolitionists in England, only then did circumstances make it possible for them to move from the fringes of politics to the center. From then on Britain engaged in an antislavery campaign that included treaty negotiations, treaty violations (when negotiations did not suffice) and outright piracy (when the ships of friendly foreign powers were forcibly boarded just to make sure there were no slaves aboard). ${ }^{41}$ In this campaign, they engaged repeatedly in double standards, treating more powerful states with somewhat more caution and respect than weaker ones. Yet the application of a double standard was far better than relinquishing the attempt to abolish slavery, which would have been the inexorable outcome if consistency had been chosen as the standard for policy. ${ }^{42}$

Not only this: the British themselves would not have been in the position of power required to foster abolitionism if they had not recurred to the advantages of enslaved labor in the previous phase of their economic history. Had they relinquished slavery two centuries earlier, they would only have aborted their own power, rendering themselves impotent for the promotion of any human rights cause. As said before, there is a natural history of human rights, which is inexorably linked to the ticking of a world-clock that measures global technological development. If the most liberal of powers were to wage

\footnotetext{
${ }^{40}$ It is interesting to remember that there is an abundance of ongoing research on morality as a product of the evolutionary process. See, for example, Leonard D. Katz (ed.), Evolutionary Origins of Morality: CrossDisciplinary Perspectives, Thorverton, UK and Bowling Green, OH: Imprint Academic, 2000.

${ }^{41}$ See Leslie Bethell, The Abolition of the Brazilian Slave Trade, Cambridge UK: Cambridge University Press, 1970; L. Bethell (ed.), Brazil: Empire and Republic, 1822-1930, Cambridge UK: Cambridge University Press, 1989, and Alan K. Manchester, British Preeminence in Brazil: its Rise and Decline, New York: Octagon Books 1972.

${ }^{42}$ A similar case can be made for the U.S. export of human rights principles abroad. See C. Escudé, "Argentina: The Costs of Contradiction", in Abraham F. Lowenthal (ed.), Exporting Democracy: The United States and Latin America, Baltimore: Johns Hopkins University Press, 1991.
} 
human rights campaigns ahead of time, it would lose in its competition with less liberal states, to the detriment of humanity's moral advance.

Fortunately, this was not the case of Britain, and by 1879 its campaign against slavery had succeeded in most of the world. Hopefully, we will eventually be able to say the same about current American efforts to wipe suicidal mega-terrorism off the face of the Earth. Success in the accomplishment of these good causes requires both extreme care for a super-state's own endowment of power, and a disposition to engage in double standards.

\section{$\underline{\text { Toward a natural history of human rights }}$}

Indeed, an analogous case of violation of human rights without injustice, justifiable in terms of the natural history of human rights, can be made regarding the late stages of World War II and the early postwar. The Allies, almost solely for the purpose of shattering civilian morale with bombs that burnt people alive, targeted some German cities. What follows is W.G. Sebald's account of the bombing of Hamburg on July 27, 1943, performed by the Royal Air Force and supported by the U.S. Eighth Army Air Force:

"Beginning at one AM, ten thousand tons of high explosives and incendiary bombs were dropped on the densely populated residential areas east of the Elbe (...). First all the doors and windows were torn from their frames and smashed by highexplosive bombs weighing four thousand pounds, then the attic floors of the buildings were ignited by lightweight incendiary mixtures, and at the same time firebombs weighing up to fifteen kilograms fell into the lower stories. Within a few minutes, huge fires were burning all over the target area, which covered some twenty square kilometers, and they merged so rapidly that only a quarter of an hour after the first bombs had dropped the whole airspace was a sea of flames as far as the eye could see. Another five minutes later (...) a firestorm of an intensity that no one would ever before have thought possible arose. The fire, now rising two thousand meters into the sky, snatched oxygen to itself so violently that the air currents reached hurricane force (...). The fire burned like this for three hours. (...) Behind collapsing façades, the flames (...) rolled like a tidal wave through the streets at a speed of over a hundred and fifty miles an hour, spun across open squares in strange rhythms like rolling cylinders of fire. The water in some of the 
canals was ablaze. (...) Residential districts so large that their total street length amounted to two hundred kilometers were utterly destroyed. (...) The refugees, numbering one and a quarter million, dispersed all over the Reich, as far as its outer borders." 43

This deed and others like it, horrendous and apparently outrageous, did not win the war for the Allies, but were a key element in the achievement of postwar stability. The German population received a powerful message: if necessary, the Allies would resort to genocide. Postwar resistance made no sense at all, even for patriots willing to sacrifice their own lives for their nation.

In Hiroshima and Nagasaki the same message was sent even more forcibly. The strategic objective was to obliterate Nazi-Fascist opposition to Proposition $\mathrm{B}^{44}$ in such a way that it would not survive after the military defeat of the Axis forces. To do this, the champions of Proposition B (i.e., of universal human rights) sent their foes the message that they would resort to mass extermination without even blinking if resistance continued (a message, by the way, that - not without consequence - remained unsent to the Iraqis in the aftermath of the 2003 war). It was this message that made it possible to eventually refrain from genocide at a grander scale, while at the same time successfully deleting NaziFascism from human affairs. Thanks to this procedure, the world was a better place during the ensuing half century.

In order to ensure this result, however, the Nüremberg Tribunal was set up, to subject Nazi war criminals to trial for the violation of Proposition B's natural law, even if they had violated no positive law and had only fulfilled their positive obligation of following the orders of their superior officers. Some were executed. Needless to say, no

\footnotetext{
${ }^{43}$ W.G. Sebald, On the Natural History of Destruction, New York: Random House, 2003, pp. 26-29. For a treatment of Allied human rights violations after the war, see James Bacque, Crimes and Mercies: The Fate Of German Civilians Under Allied Occupation, 1944-1950, London: Little Brown, 2003. For a treatment of Communist atrocities against ethnic Germans after the war, see Alfred-Maurice De Zavas and Charles M. Barber, A Terrible Revenge: The Ethnic Cleansing of the East European Germans, 1944-1950, New York: St. Martin's, 1994. For another treatment of the Allied bombing of German civilians when the war was already won, and German civilian losses in general, see Hermann Knell, To Destroy a City: Strategic Bombing and Its Human Consequences in World War II, New York: Da Capo, 2003.

${ }^{44}$ As Islamic fundamentalism today, Nazi-Fascism was a potential ally of Proposition A insofar as it did not recognize a universal set of basic human rights. It asserted the superiority of one biologically defined subset of the human species it called the "master race", very much as radical Islam today asserts the right to rule of Mohammed's followers. The struggle against Nazi-Fascism was a natural war of the modern era, analogous yet different from the natural war of neomodern times we face today.
} 
such legal procedure was applied against the men responsible for the bombing of Hiroshima and Nagasaki. The selective violation of human rights by the defenders of human rights, and the application of a double standard in the establishment of legal procedures against perpetrators of crimes against humanity, was the most effective mechanism for the (relative) triumph of human rights in that phase of their natural history.

\section{The Security Council as a prelude to Empire}

Simultaneously, the victors had established an intergovernmental organization to administrate the principal problems arising in the postwar. It initially excluded the vanquished, and was called the "United Nations", no less than the official name of the victorious Allied coalition. An oligopolic Security Council with global intervention prerogatives was created, which included five permanent members endowed with veto power. These five were none other than the states acknowledged as the great powers of the winning side in the world war: they have that status through right of conquest. The structure of the Council is the direct reflection of a structure of power: that of the world in 1945. The right of the United States, Great Britain, Russia, China and France to be the virtual owners of the Council emerges from the successful use of force, and it could not be otherwise, for in relatively foundational situations law tends to derive from order and not vice-versa.

Afterwards, the United Nations attempted to legislate for the world and establish some jurisprudence, with varying degrees of success. The amnesia that characterizes human beings in middle- and long-term historical processes is the reason why most educated people today have forgotten that the United Nations emerged from an act of force. During decades they administrated some global issues constructively, in such a way that this organization, born of the genocidal bombings of Hamburg and Dresden, Hiroshima and Nagasaki, made some valuable contributions to humanity. Once again, a law engendered by force and conquest was applied against new transgressors in a selective manner, using double and indeed multiple standards. This was beneficial to humankind, which would have become impotent before tyranny and aggression if consistency had been the rule, in such a way as to punish every aggression or no aggression at all, every tyranny or no tyranny whatsoever. 
But because the structure of the Security Council of the United Nations reflects a structure of power, it made sense while the latter lasted. Simplifying, the Organization of the United Nations was created by the victorious violence of the United States in postwar circumstances in which a bipolar world had emerged. When bipolarity gave way to unipolarity as a consequence of the collapse of the Soviet Union and the consolidation of overwhelming American military superiority, ${ }^{45}$ it became an anachronism. What is to be expected under these circumstances, and what is probably desirable, is for the United States to recur to coalitions or unilateral action whenever it does not find consensus in the Council for a policy it considers of the highest priority. This double standard is no different or more scandalous than the ones recurred to in previous stages of history, either by other or the same actors.

Indeed, historical experience clearly shows that ethical progress on a global scale, as well as the preservation of acceptable levels of world security (a categorical imperative in an era of weapons of mass destruction), require the wise administration of double standards by a hegemonic power, not only through the selective use of force to prevent international aggression and consolidate human rights in other states, but also through occasional violations of these norms by the superpower itself. Insightful theorists of both the Right and the Left have agreed that: "The sovereign stands outside the juridical order and, nevertheless, belongs to it, since it is up to him to decide if the constitution is to be suspended (...)". Over and beyond what positive laws may establish, from the times of Grotius it is well known that this "paradox of sovereignty" is reiterated in all foundational moments and in all states of exception. ${ }^{46}$

In the present stage of the natural history of the world-system, this legitimate license to deviate occasionally from the norm of non-aggression and from natural law itself, both at home and abroad, for the sake of the preservation of its own power, must be limited to only one state ${ }^{47}$ with overwhelming power and extraordinary rule-making capabilities in the

\footnotetext{
${ }^{45}$ See Paul Kennedy, "The eagle has landed", Financial Times, February 1, 2002 and Michael Ignatieff, "The American Empire (Get Used To It)", New York Times Magazine, January 5, 2003.

${ }^{46}$ Giorgio Agamben, Homo Sacer: Sovereign Power and Bare Life, Stanford, CA: Stanford University Press, 1998, p. 15, citing Carl Schmitt, Politische Theologie (1922). Grotius was among the first to advocate that a state had the right to violate ethical codes in times of exception. Presently, a similar opinion with nuances is expressed (among others) by Alan Dershowitz, with whom I concur. He is of the opinion that the use of torture in extreme circumstances must be regulated and should be implemented with a legal warrant.

${ }^{47}$ This idea simply limits to one state what Grotius granted to all under the "state of exception".
} 
interstate system. ${ }^{48}$ Freedom to launch preemptive wars and violate natural right cannot be generalized without unleashing chaos and forever relinquishing the aspiration of moral progress. Preferably, this state should be a hegemonic power with a liberal-secular cultural matrix. Its authority, which is natural, includes the right to wage a just war against an enemy of humanity.

\section{$\underline{\text { An "omega point" }}$}

On the other hand, it seems reasonable to assert that the greater the concentration of power in relation to matters of war and peace, the lesser the need for double-standards in the implementation of the hyperpower's human rights policy. Conceivably, the natural history of human rights could include an "omega point" in which a universal state would no longer have a functional need to violate them, and hence no justification compatible with an incremental conception of global ethical progress.

That in the historical context of an era of weapons of mass destruction, an overwhelming concentration of interstate power seems to be the only way of increasing the likelihood of survival of the species and of consolidating its moral progress, ${ }^{49}$ was perceived as early as 1969 by such a liberal thinker as Hannah Arendt:

"The chief reason why war is still with us is neither a secret death wish of the human species, nor an irrepressible instinct of aggression, nor (...) the serious social and economic dangers inherent in disarmament, but the simple fact that no final arbiter in international affairs has yet appeared on the political scene. Was not Hobbes right when he said, 'covenants, without the sword, are but words'? Nor is a

\footnotetext{
${ }^{48}$ The prevalence of an interstate system with an incipiently hierarchical structure in which there are three types of states with different functions, rule-makers, rule-takers and rogue states (defined as states without rule-making capabilities that notwithstanding challenge the rules set by the rule-makers), is developed most completely in C. Escudé, Foreign Policy Theory in Menem's Argentina, Gainesville: University Press of Florida, 1997. It is also found summarily in C. Escudé, "An introduction to peripheral realism and its implications for the interstate system: Argentina and the Cóndor II missile project", in Stephanie Neuman (ed.), International Relations Theory and the Third World, New York: St. Martin's Press, 1998.

${ }^{49}$ The advent and proliferation of weapons of mass destruction has bestowed a new irrelevance upon some philosophical stances. Isaiah Berlin's rejection of monist positions, for example, no longer seems acceptable. Monism supposes that there is an ultimate instance in which all human values can be rendered harmonious. It is easy to reject a Marxist monism emerging from the conception that history irremediably advances towards a classless society. But it is much more difficult to reject a monism that arises from the empirical fact that humanity is heading towards self-destruction at roller-coaster speed. The near certainty of a human holocaust imposes a hierarchy of values converging on the survival of the species. Once again, reality is reconstructed
} 
substitute likely to appear so long as national independence, namely, freedom from foreign rule, and the sovereignty of the state, namely, the claim to unlimited power in foreign affairs, are identified." ${ }^{, 50}$

I have not found a more convincing argument of the need for "Empire" than Arendt's, whose reasoning is not contaminated by political calculations, as are the writings of those who delve on the issue in the 21 st Century. During the Cold War, when she wrote, it was unthinkable that the United States might become such an Empire. Thus, she did not straightjacket her intelligence with political considerations alien to her clear line of reasoning. What she is telling us (echoing segments of Clarence Streit's Union Now ${ }^{51}$ ) is that if lasting peace is to prevail (and this is essential for human survival in an era of weapons of mass destruction), a global Leviathan must emerge to administrate issues of global security, without interfering unduly in local government. ${ }^{52}$ But because many states are not willing to abide by non-proliferation treaties (they insist on what Arendt calls a "claim to unlimited power in foreign affairs"), occasions may unavoidably arise when a preemptive war must first be waged. As Giorgio Agamben argues, the constitution of sovereignty is of necessity violent. And a human species that is globalized by technology and must confront planet-wide life-or-death issues requires a universal sovereign. This final phase of the natural history of conquest is, in every sense, revolutionary. ${ }^{53}$

Under these circumstances, the right of the victorious hegemon to world tutelage will in no way be inferior to that of the triumphant five Allies of World War II to appoint themselves as veto-wielding permanent members of a Security Council vested with

through the possibility of death. For Berlin's rejection of monism, see Four Layers of Liberty, London: Oxford University Press, 1969, p. 169.

${ }^{50}$ Hannah Arendt, On Violence, Chicago: University of Chicago Press, 1969, p. 9. For one of the most cogent recent defenses of a liberal neo-imperialism, see Robert Cooper, The Breaking of Nations: Order and Chaos in the Twenty-First Century, Boston, MA: Atlantic Monthly Press, 2004.

${ }^{51}$ Clarence Streit, Union Now, New York: Harper \& Bro, 1939.

${ }^{52}$ Full of sad resignation, Arendt also provides us with a darkly poetic definition of the anarchy of world politics : "To speak of 'the priority of war-making potential as the principal structuring force of society', (...) to conclude that 'war itself is the basic social system' (...) sounds (...) plausible. (...) Instead of war being 'an extension of diplomacy (or of policy, or of the pursuit of economic objectives'), peace is the continuation of war by other means." (Ibid. p. 5)

${ }^{53}$ The essential difference between this would-be American conquest and the frustrated Napoleonic conquest lies, of course, in world-time. With the human species globalized, reflections on "constituting power" originally applied to domestic orders become applicable to the world order. One can even read Antonio Negri's work on Il Potere Constituente (Milan: SugarCo, 1992) as a metaphor of the coming of Empire. 
authority to intervene militarily anywhere in the world. ${ }^{54}$ Indeed, the right of Empire will not emerge from a less legitimate source than that of the United Nations. But the Empire may be much more expedient than the United Nations, and it may be indispensable for the survival of humankind.

As can be appreciated, this rationale for Empire is coined not in terms of the interests of the United States, but rather in those of a human species beleaguered by the development of weapons of mass destruction and by the ensuing need to prevent future total wars at all costs. ${ }^{55}$ Our outlook is cosmopolitan. It is anchored in very different terms from what has been called the Cheney-Rumsfeld-Wolfowitz-Perle ${ }^{56}$ vision of the US role in the world, although there is a measure of convergence in its normative consequences. It is not based on actual US objectives but on a conception of what these objectives should be, given the fact that the world needs a global Leviathan and the United States happens to be the only candidate for the job.

This is not necessarily of our liking. ${ }^{57}$ It is the historical process that put the United States where they are, in Humanity's hour of dire danger. Paraphrasing Jorge Luis Borges, "no nos une el amor sino el espanto". 58 The Americans are obligated to a Kantian categorical imperative: they must perform this function whether they like it or not. They

\footnotetext{
${ }_{55}^{54}$ Under the provisions of Chapter 7 of the Charter of the United Nations.

55 The endangerment of the environment and the biosphere are equally alarming threats to the human species, and a potent reason why a global concentration of power to enforce conservationist measures should be sought. The problem will not be addressed here, however, because due to the insensitivity of the U.S. government, we are even further away from confronting that issue than to containing the proliferation of weapons of mass destruction. Notwithstanding, what is most urgent is the constitution of the Leviathan itself, empowered to act globally and unilaterally. Once the environmental crisis visibly deepens, it will act, though it may be too late.

${ }^{56}$ In reference to the "Project for a New American Century". Most frequently cited as a blueprint for this U.S.-centric rationale is the famous 46-page classified document titled "Defense Planning Guidance", by Paul Wolfowitz (Undersecretary of Defense for Policy in the administration of George Bush, Sr., and Deputy Secretary of Defense under George W. Bush) and I. Lewis Libby (Principal Deputy Under Secretary for Strategy and Resources during the Bush (Sr.) administration and now chief of staff to Vice-President Cheney). The paper was leaked to the Washington Post and the New York Times on March 11, 1992. The document parallels statements of Richard B. Cheney and Gen. Colin L. Powell when they served as Defense Secretary and chairman of the Joint Chiefs of Staff of the Bush (Sr.) administration.

${ }^{57} I$ would not have put the US where they are: among the advanced democracies, I would have preferred a more "sophisticated" nation. But it is not a matter of choice. It is for this reason that as advisor to Argentine foreign minister Guido Di Tella during the early 1990s I advocated for Argentine disarmament. In so doing I was advocating for Argentina's abdication from an active role in the military power game. When I did this it was with the expectation that the United States would occupy its sovereign place, because this is what humanity needs.

58 "We are not united by love but by horror".
} 
must wage preemptive wars to root out weapons of mass destruction from the more dangerous rogue states. They must prevent even close allies from competing with them for military power, because today's friendly cooperative relations can feasibly become the cold war of tomorrow, and eventually, the future total global war and Holocaust. This is the one occasion in its entire history in which mankind has come close to the possibility of “constituting" a global Leviathan: we are yet so far, but we have never been closer. Because every century has been witness to a total war, and because with the development of weapons of mass destruction the next one will spell doomsday, the opportunity should not be wasted. ${ }^{59}$

In Argentina, we have abided by to our peripheral categorical imperative, contributing to human security. When during the 1990s we deactivated our ballistic missile project and signed the Nuclear Non Proliferation Treaty, we abdicated from the sovereign right to develop weapons of mass destruction. Our policy isolated Brazil, who then acquiesced to U.S. pressures and also signed the treaty. Those of us who advised foreign minister Guido Di Tella advocated for these policies, not so that India and Pakistan could have their bombs, but to make it easier for the United States to prevent this from happening. By disarming, we bestowed on the United States an additional measure of power. It must be demanded that they use it. "Peripheral realist abdication" is the other side of the coin of Empire, because it would be utopian to advocate for universal disarmament.

\footnotetext{
${ }^{59}$ Thanks are due to David Sheinin for having referred me to a Canadian author, Ellen Meiksins Wood (Empire of Capital, London \& New York: Verso, 2003). Many authors, including the one cited, ask "who will guard the guardian?" Indeed, who guards the guardian within a domestic order? A Parliament, one may answer, and a judiciary. They took centuries to develop. How long will the global Leviathan take to develop its own domestic guardians of the global state? Maybe centuries, maybe less, but this is all part of the natural history of the world-system. It is much scarier to think that our species will not develop a global Leviathan for the purpose of coping with global issues. Following Hobbes' logic, in an era of weapons of mass destruction a global Leviathan is necessary for the same reason that smaller Leviathans were necessary before that, to prevent the individual from leading a life that was "nasty, brutish and short". Now it will be the species as a whole whose life will be so fated unless the global Leviathan is born. All the violence proper of constituting processes will be unleashed at its creation, however (see notes on Carl Schmitt and Giorgio Agamben above). On the other hand, the need to seriously confront environmental issues, which may soon be perceived as urgent, will probably generate a drive toward authoritarian government and unilateral international actions. How else will transgressing individuals, businesses and states be dealt with? This is also part of natural history. The Pentagon already warns that climate change has become a U.S. security problem. Liberals have long pressed for the problem to be acknowledged. They will live to regret it. The next phase in human history will probably be closer to dictatorship than to liberal democracy, everywhere in the world. See "Now the Pentagon tells Bush: climate change will destroy us", The Observer, February 22, 2004.
} 
Thus far, the United States is failing in its efforts to prevent proliferation. Its errors lie not in the doctrine of preventive war, but in their timidity in its implementation.

\section{The end of history}

When he hypothesized that the end of history was near, Fukuyama was intuitively right, yet he was theoretically mistaken in his reasoning that this outcome would be the result of capitalism's triumph over communism. An age characterized by the advent of weapons of mass destruction was fated to come at some point in human evolution for the sheer reason that the advance and accumulation of science and technology is one of the few anthropological constants in history. The human being seldom de-invents anything. When the Iron Age replaced the Bronze Age never again did we fight with bronze weapons. And when in 1945 the atomic bomb was invented it was here to stay. The same is sadly true for other weapons of mass destruction. Indeed, we can properly refer to such a thing as a "natural history of destruction". 60

A similar reasoning holds for a veritable "globalization": irrespective of the historical process which made capitalism succeed over competing economic systems, and no matter which economic system ultimately became hegemonic, because of the advance of technology the planet Earth had eventually to become a single unit. A non-technological civilization could not have prevailed in the long term of human history because sooner or later it would have been conquered by a technological culture endowed with the sort of power that emerges only from the manipulation of nature made possible by science.

Moreover, although the political, commercial and financial dimensions of globalization as it stands today are reversible, the globalization of the means of destruction is absolutely irreversible. One could even say that the forces that made these phenomena inevitable are derived from the genetic code of the homo sapiens. ${ }^{61}$ Indeed, most relativists,

\footnotetext{
${ }^{60}$ There are, as Wallerstein said, some great watersheds in the history of humankind, such as the Neolithic or agricultural revolution. Several others followed and I will emphasize only the last two: the $15^{\text {th }}$ Century Iberian expansion overseas (which marks the beginning of what he calls the modern world-system) and both the 1945 bombing of Hiroshima and the 2001 terrorist attacks against Manhattan and the Pentagon (which together symbolize the advent of an age of weapons of mass destruction and what I call the neomodern worldsystem).

${ }^{61}$ Quite obviously, I disagree with Wallerstein in his belief that "there is no inevitable secular line of human history" (op. cit. 1991, p.107). There is such a line, and it stems from the accumulation of technology. What prevents Wallerstein and other historical materialists from understanding this is that their economicism leads them to: (1) think in terms of the development of the means of production and disregard that of the means of
} 
including so-called postmodernists, are wrong on this score. It is because of the empirical fact of the development of the means of destruction that we must revert to an evolutionary paradigm in social science. Once again, we run into the lethal reconstruction of reality. Wallerstein's capitalist world-economy was certainly not inevitable, but both the advent of weapons of mass destruction and globalization were fated to become a trait of the worldsystem at one time or another, and once with us, they would be here for good, the alternative being, in all likelihood, doomsday. ${ }^{62}$ Once this era befell upon us, the alternative is not "Post-America", as Wallerstein predicted and perhaps desired. ${ }^{63}$ It is Post-Humanity. With this watershed the modern world-system suffered its demise. A capitalist mode of production, a massive mode of destruction and the democratization of the means of mass destruction through proliferation characterize the neomodern world-system, as it evolved after the collapse of the USSR. With these developments we are approaching the end of history, but not as Fukuyama envisioned it. ${ }^{64}$ The end of history could never have been the consequence of the denouement of a clash of ideologies or of models of economic organization. It is linked to the globalization of the means of destruction and, discarding the Apocalypse, it can only be the product of the concentration of awesome might in a single

destruction; (2) perceive globalization exclusively as a product of late capitalism, instead of understanding it as a long-term process of technological accumulation that led to the transformation of the planet into a single unit in terms of transportation, communications and the possibility of destruction.

${ }^{62}$ Economicist reductionism is what prevents Wallerstein from bringing the advent of weapons of mass destruction into his analysis. This reductionism is patently clear when he says: "The modern world-system is a capitalist world-economy. That is a description of its formal structure and its mode of production." ("Typology of Crises in the World-System", op. cit. 1991, p 107). In reality, the modern world-system was composed of two subsystems of similar standing: a capitalist world-economy and a fragmented securitystructure, which since 1945 is increasingly characterized by the existence and proliferation of weapons of mass destruction. Paraphrasing Wallerstein and Marx with a plus, this is a description of its formal structure, its mode of production, and its potential mode of destruction. Moreover, since the launching of the first Sputnik in 1957 the USSR became a military giant capable of destroying the world (i.e., very much a part of the "core" of a fragmented security-structure), but was not part of the core of the world-economy. When the Soviet Union collapsed, the Russian Federation entered the capitalist world-economy as part of the periphery, yet from the point of view of the neomodern world-system's fragmented security-structure it continued to be part of the core.

${ }^{63}$ I. Wallerstein, ibid, loc.cit.

${ }^{64}$ I originally developed these ideas in C. Escudé, "The European Union and Global Security in the Postmodern World-System", in Ryszard Stemplowski (ed.) The European Union in the World System Perspective, Polish Institute of International Affairs, Warsaw 2002; in "When Security Reigns Supreme: The Postmodern World-System vis-à-vis Globalized Terrorism and Organized Crime", in R. Stemplowski (ed.), Transnational Terrorism in the World System Perspective, Polish Institute of International Affairs, Warsaw 2002; in C. Escudé, "Unia Europejska i globalne bezpieczenstwo w ponowoczesnym swiecie", in Polski Przeglad Dyplomatyczny, Vol. 2, № 1 (5) 2002, and in Карлос Эскуде (Carlos Escudé), "Европейский Союз и глобальная безопасность в мировой системе постсовременности (world-system)", in Eвропа, Vol. 2 (3), 2002, p. 96-130. 
state, approximating it to a world Leviathan. The book he should have written is The End of History and the Last War, for despite the defeat of communism a major war was still needed to ensure such an outcome. After September 11, however, the title to that still unwritten volume must become The End of History and the Just War.

This necessary and just war, which has barely begun, will inevitably bring with it many subordinate injustices, which will be committed by the very warriors who will hopefully bring ultimate peace and justice to humankind. Yet this is not a self-betrayal. The liberal-secular West's great step forward, ethically, has been the unraveling of a natural law that acknowledges certain universal rights and duties of the human individual. But this formulation is not tantamount to its universal application. Cynical as it may sound, the distance between denying and acknowledging the universal rights of men and women is far greater than that between acknowledging and complying with these principles.

In the case of a hyperpower, the natural law, both at home and abroad, must be upheld only when it is affordable, because in an era of weapons of mass destruction the constitution of a universal sovereign is a categorical imperative. As Grotius would have argued, survival and the power to ensure it come first. A hegemonic power is fated to violate its natural commandments. What is important is that it understand that they are commandments, and that they are natural. 